Introduction

\title{
ON PACIFICATION: INTRODUCTION TO THE SPECIAL ISSUE
}

\section{MARK NEOCLEOUS, GEORGE RIGAKOS, TYLER WALL}

In 1957 at Supreme Headquarters Allied Powers Europe (SHAPE), one of NATO's two strategic commands, a speech was given by General Allard of France. France had by that time given up what had become known as its 'dirty war' in Indochina, but was happy to continue a series of wars elsewhere which were hardly any 'cleaner'. Such wars were understood by NATO and its allies, but also by their opponents, as 'revolutionary wars', and this was the subject of Allard's speech: how to defeat the revolution.

Allard's view was that war against the various communist and socialist movements then in existence had to involve 'pure' military action, but that this alone would not be enough. Also needed was a second group of actions, grouped together because they worked in unison: psychological action, propaganda, political and operational intelligence, police measures, personal contacts with the population, and a host of social and economic programs. Of this combined action Allard notes: 'I shall classify these various missions under two categories: Destruction and Construction. These two terms are inseparable. To destroy without building up would mean useless labor; to build without first destroying would be a delusion'. He then goes on to expand on these terms. The meaning of 'destruction' is fairly clear: the co-ordinated activity of army and associated state powers to 'chase and annihilate ... deal spectacular blows ... and maintain insecurity'. 'Construction', however, means 'building the peace', 'organizing the people', persuading the people 'by the use of education' and, ultimately 'preparing the establishment of a new order'. He adds: 'This is the task of pacification' (cited in Paret, 1964, 30-1).

It is remarkable how often a comment along these lines appears, again and again, in text after text, in the state discourse of pacification (see Neocleous, 2011a; 2011b). The general theme in such texts is that pacification needs to be understood not just as military action to crush the enemy insurgency, but also a broader and far-reaching action to construct a new social order. Such an order would be one in which insurgency would not and could not occur, but it would also be an order in which capitalist accumulation might flourish. General Maurice Challe, for example, liked to talk about the 'positive' element of the campaign in Northern Algeria for which he was responsible in 1960, as one which continued the colonial campaigns elsewhere. Zones would be increasingly pacified as army engineers built roads through to its most inhospitable areas, schools and clinics 
were constructed, and 'civilization' allowed to flourish (see Horne, 1987, 338). What might be described as 'pure' military actions needed to be combined with a wider and more diverse range of political technologies to create a viable social order.

The underlying motivation for this political technology has always been the coercive, often brutal, imposition of capitalist property relations through primitive accumulation. In this sense, contemporary pacification is the ideological iron fist and velvet glove aimed at the continued 'forcible expropriation of the people' through a 'whole series of thefts, outrages, and popular misery' (Hammond and Hammond, 1913: 27-28) dating back before the Enclosures. Not only was a system of pacification required to curtail subsistence but, as one eighteenth century Lincolnshire noble put it: 'the lower classes must be kept poor, or they will never be industrious' (cited in Perelman, 1983: 38). The extraction of surplus, as Adam Smith (1981: 387) admits, can 'be squeezed out of [the labourer] by violence only, and not by any interest of his own' if he can subsist otherwise such as through access to communal land. This, in short, is the foundational bourgeois logic for the compulsion to pacify.

Thus, there is nothing peculiarly 'French' about Allard's approach. The way the French understood pacification in the 1950s was more or less exactly the way every other colonial power understood it going back to the sixteenth century and forward into the second half of the twentieth century and now the twenty-first. And the reason they all understood it in the same way is because the creation of durably pacified social spaces, to use Norbert Elias's phrase (1996), is inherent to the political project of bourgeois modernity both through imperial domination and domestic control. 'Pacification' thus serves as a linchpin for investigating the coercive economic and social formation of populations; it is a tool for grasping the state-sponsored destruction and reconstruction of social order. 'Pacification' places at the forefront of our analysis a consideration of the confluence of military conquest and the fabrication of social order: it advances our understanding of the world capitalist economy and its social relationships by arguing that it is also a 'world military order' undertaken through a whole host of 'police actions'. The articles in this special issue of Socialist Studies seek to give some critical purchase to this idea of pacification, and, in so doing, aim to draw direct theoretical connections between socialist struggles aimed at imperial domination and a wide array of resistances that seem far more local and domestic.

The starting point of the articles is that with such a rich history and such a wide set of connotations - on the one hand, defeating communist and radical movements among the people, and thus pointing us to the complex techniques used to do so; on the other hand, of building a new order and likewise pointing to a set of related and equally complex techniques - 'pacification' would seem to have huge potential in our understanding of state and corporate power and its role in the fabrication of bourgeois order. This special issue is a first, rudimentary, step to test just how far we might push the 
category as a keyword in socialist studies. For us, however, this step is being undertaken under the umbrella of the critique of security, and this perhaps needs a little explanation.

In October 2010 a small group of academics and graduate students convened for two days at Carleton University, Ottawa, to discuss ideas based on the possibility of challenging the hegemony of security. Throughout the discussions one of the themes was to ask what it might mean to talk about a project that we might call 'anti-security'. The outcome of that first meeting was an edited volume, Anti-Security (Red Quill Books, 2011). At that initial meeting it seemed immediately apparent that 'pacification' might hold tremendous promise as a vehicle for theorizing police power and the ways in which such power is linked with state violence exercised against radical, democratic social action and for the protection of bourgeois private property rights. A further meeting, with some of the original group but also with new members, took place in Nicosia in September 2012 under the auspices of the European Group for the Study of Deviance and Social Control. Although the central theme was again anti-security, one of the main topics of discussion to re-emerge was the possibility of using this category 'pacification' for radical politics and critical theory. As a critical concept, pacification had already been developed by Neocleous (2010, 2011a) along these lines, but his chapter entitled 'Security as Pacification' (Neocleous, 2011b), Rigakos' (2011) application of the concept in the same anthology, and their co-authored 'Declaration' based on the group's discussion (Neocleous and Rigakos, 2011), stimulated continued interest in exploring how 'pacification' might carry enough critical weight for the group to make sense of the hegemony of security. To make sense, that is, of how state and capital operate under, through and with the logic of security and to find ways to subvert this.

We thus set out to consider a number of related questions. First, to what extent can we push the idea that at the heart of pacification is not just the crushing of resistance but also the construction of bourgeois order? Second, how might this be connected to the related idea that pacification is integral to capitalist accumulation? Third, what does pacification mean for our understanding of the nexus of war powers and police powers within the bourgeois state? Fourth, might we understand pacification under the sign of security? Conversely, and fifth, just how far can we push the idea of security as pacification? The essays in this special issue are a first attempt to explore these questions, to pursue the idea of security as pacification, and to consider pacification as the production of bourgeois order in general.

To consider the production of bourgeois order in general requires an approach which seeks to grasp the social totality, which of course means grasping it historically. This has two major implications. First, as much as one finds 'pacification' within any disciplinary home, it is firmly ensconced within military history and war studies. There, it is often used as a concept pertaining solely to 'small wars' and thus used to dismiss such wars as little more than a sideshow to the progress of capitalist modernity. But such wars are anything but 'small': as a colonizing force, they are clearly of major historical 
significance and remain at the very heart of capitalist modernity. Our appropriation of the term pacification, with its historical roots in wars of conquest and primitive accumulation, reinforces its analytic utility in that it holds the potential to demonstrate how this history weighs on and is often perpetuated in the present. The study of pacification is a vehicle for the radical re-examination of the fabrication and maintenance of capitalist relations by taking seriously the formative logics of security entrepreneurs from the 'police scientists' of the Enlightenment period to their myriad contemporary security planners and policers. The second implication is that as a category of critical socialist theory 'pacification' has no disciplinary home. By lacking disciplinary history, 'pacification' opens itself to appropriation for critical theory. It affects struggle and critical analysis at multiple levels by mirroring and subverting the very pre-disciplinary logics where imperial planning and policing projects were first advocated as part of a wider project of political economy (see Rigakos et al. 2009). It challenges the ever-increasing intellectual division of labour that segregates 'security' as a special issue to be discussed only by experts in military history and war studies. It mimics the pre-disciplinary thinking that facilitated the technocratic proliferation of security planning through everincreasing intellectual divisions of labour: a form of risk thinking that now colonizes almost every corner of contemporary scholarship. Contributors to this anthology, on the contrary, advance an understanding of contemporary security as pacification that is central to the normal violence of bourgeois dispossession and the imposition of capitalist social relations. This narrative of imperial domination and the fabrication of a world capitalist system through enforced property relations is certainly an old story for Marxists (e.g. Luxemburg 1913; Lenin, 1916), but in this special issue we are interested in more than just this story. We are interested in appropriating and critically theorizing a notion that is at the very root of the thinking and planning that built up this world capitalist system. 'Pacification' is thus a notion that has promulgated a wide series of policing actions both domestically and imperially that, until now, silently subtended the global economic system. A notion we wish to excavate and appropriate for critical inquiry.

The essays offered in this special issue are therefore intended as a step in that appropriation. They are meant to be read as a group. They are work in collective progress, and collective work in progress. They are a working through of some of the issues in the concept of pacification. They are meant to be read with one another, alongside one another and, in some cases, against one another. Such is the nature of collective work that it benefits from this broad involvement and, in so doing, seeks to strengthen both socialist theory and political struggle. 


\section{References}

Elias, Norbert. 1996. The Germans: Power Struggles and the Development of Habitus in the Nineteenth and Twentieth Centuries (1989), trans. Eric Dunning and Stephen Mennell. New York: Columbia University Press.

Hammond, J. L. and Barbara Hammond. 1920. The Village Labourer: 1760-1832. London: Longmans, Green and Co.

Horne, Alistair. 1987. A Savage War of Peace: Algeria 1954-1962. London: Papermac.

Lenin, V.I. 1916. Imperialism: The Highest Stage of Capitalism: An Outline. London: Penguin, 2010 reprinted.

Luxemburg, Rosa. 1913. The Accumulation of Capital. Translated by: A. Schwarzschild in 1951. London: Routledge Classics edition, 2003 reprinted.

Neocleous, Mark. 2010. 'War as Peace, Peace as Pacification', Radical Philosophy, 159: 817.

Neocleous, Mark. 2011a. “A Brighter and Nicer New Life": Security as Pacification', Social Legal Studies. 20(2): 191-208

Neocleous, Mark. 2011b. 'Security as Pacification'. In Anti-Security, edited by Mark Neocleous and George S. Rigakos. Ottawa: Red Quill Books.

Neocleous, Mark and Rigakos, George S. 2011. 'Anti-Security: A Declaration'. In Mark Neocleous and George S. Rigakos, eds. Anti-Security. Ottawa: Red Quill Books.

Paret, Peter. 1964. French Revolutionary Warfare from Indochina to Algeria: The Analysis of a Political and Military Doctrine. London: Pall Mall Press.

Perelman, Michael. 1983. Classical Political Economy: Primitive Accumulation and the Social Division of Labor. Totowa, NJ: Rowan and Allenheld.

Rigakos, George S., John L. McMullan, Joshua Johnson and Gulden Ozcan, Eds. 2009. A General Police System: Political Economy and Security in the Age of Enlightenment. Ottawa: Red Quill Books 
Socialist Studies / Études socialistes 9 (2) Winter 2013

Rigakos, George S. 2011. “"To Extend the Scope of Productive Labour”: Pacification as a Police Project'. In Mark Neocleous and George S. Rigakos, eds. Anti-Security. Ottawa: Red Quill Books.

Smith, Adam. 1981. An Inquiry into the Nature and Causes of the Wealth of Nations. Indianapolis: Liberty Fund. 